\title{
Implementation of Federal Character Policy in Nigeria Civil Service
}

\author{
Timothy Onimisi, Ku Hasnita Ku Samsu, Mohd Mahadee bin Ismail, Murni binti Wan Mohd \\ Nor
}

\begin{abstract}
Disturbed with the disparity in the employment distribution in the civil service, the Nigerian government enacted the Federal Character Policy to ensure equality in employment distribution in the country's civil service. Unfortunately, the policy appears to be unsuccessful in its implementation because disparity still characterizes employment distribution in the Nigerian civil service. This has led to the rivalry, disharmony, and discontent in the service. This paper explores measure aimed at ensuring implementation of the Federal Character Policy in the Nigerian civil service employment distribution. In order to meet the objective of the paper qualitative research method adopted while purposive sampling used in selecting the informants interviewed while the relevant document was equally analyzed. Interpretative Phenomenological Analysis was adopted for data analysis. The paper found that the implementation of the policy can be ensured with committed leadership, orientation and training. The paper provided valuable strategies that will ensure the implementation of the Federal Character Policy in the Nigerian civil service employment distribution and importantly it provided helpful insight for policies that are facing similar implementation setback
\end{abstract}

Keywords: Civil Service, Federal Character Policy, Implementation, Nigeria.

\section{INTRODUCTION}

Violence remains entrenched in Nigeria today simply because of rivalry between the ethnic groups in an attempt to control power at the central and the crisis of injustice, marginalization, and inequality (Ugoh \& Ukpere, 2012). The problem of inequality and marginalization in Nigeria are systematic and overlapping in nature as it tent towards regional, religion and ethnic cleavages which are made complex by factors such as geography, history, diverse cultural orientation, unequal natural resources endowments, different in educational attainments, bureaucracy, socioeconomic and political issues as well as near absence of concrete policy (Mustapha, 2009; Ugoh \& Ukpere, 2012). The continuous imbalances and perceived injustice in Nigeria brought about the need to formulate state policy actions to correct or mitigate the prevailing concerns of the citizens and grievance, thus Federal Character Policy came to ensure equal access for both minority and majority groups in nations (Oyedeji, 2016). The conception and subsequent enactment of the Federal Character Policy in Nigeria were to

Revised Manuscript Received on September 22, 2019.

Timothy Onimisi, Department of Political Science, Federal University Lokoja, P.M.B. 1154, Lokoja, Kogi State, Nigeria.

Ku Hasnita Ku Samsu*, Faculty of Human Ecology, University Putra Malaysia, Selangor, Serdang, 43400, Malaysia

Mohd Mahadee bin Ismail, Faculty of Human Ecology, University Putra Malaysia, Selangor, Serdang, 43400, Malaysia

Murni binti Wan Mohd Nor, Faculty of Human Ecology, University Putra Malaysia, Selangor, Serdang, 43400, Malaysia promote peace co-existent, foster unity, advance national integration among the diverse socio-ethnic group that makes up the country and importantly ensures equal access to state own resources which include employment distributions in the Nigerian civil service, agencies, and parastatals.

Nigeria is a multi-ethnic and multi-cultural society with a lot of issue of margination and disparity in governmental activities and especially in employment distribution into government agencies, parastatals, and departments. The issue of disparity in employment distribution among the various components or states were the over three hundred ethnic groups that made of the country are found remains a huge problem for the government and concern citizens. The federal government of Nigeria a few decades ago became with the Federal Character Policy to ensure equal employment distribution among the thirty-six states and Federal Capital Territory. Unfortunately, the implementation of the Federal Character Policy in the Nigerian civil service seems to be unsuccessful as disparity remains inherent in the employment distribution in the service. This apparently shows that implementation remains a big challenge. It is against this backdrop that this paper attempt to provide the impetus that would ensure and guarantee the implementation of Federal Character Policy in the Nigeria civil service. The paper is divided into five sections which are the introduction, literature review, methodology, ensuring the implementation of the Federal Character Policy in Nigerian civil service which represent finding and discussion and the conclusion.

\section{LiteratURE REVIEW}

\section{A. Federal Character Policy}

One of the major issues confronting countries in Africa is how to ensure equitable allocation of resource especially in the area of recruitment and distribution of employment across all the geo-political zones and states in the country. Therefore, in order to accommodate all the sections of the country, the Nigerian government enacted the Federal Character Policy as a means of addressing any perceived employment inequality. The literature on Federal Character Policy (FCP) has highlighted and attributed several meanings to the Federal Character Policy, which is believed to have nationalistic goals aimed at building a united country through equal employment distribution. Cornelius \& Greg (2013) see the FCP as a nation-building policy aimed at uniting existing autonomous regions and ensuring equal opportunities that will invariably translate to peaceful coexistence among the citizenry. Similarly, Okorie and Onwe (2015) consider the introduction of the Federal Character Policy as a measure 
targeted at solving the prevailing issues of disunity and diversity in the country through the public sector, especially the employment process into the Nigerian civil service.

Ugoh and Ukpere (2012) agree with the integrative explanation of the Federal Character Policy they view the Federal Character Policy as an integrative mechanism of the government aimed at bringing together different groups in Nigeria irrespective of their ethnicity, language, geographic and religious diversity. Ugoh and Ukpere (2012) equally see the Federal Character Policy from the integrative perspectives like other scholars who see the policy as fostering unity, equality, peace, accessibility and the promotion of integration of the disadvantaged states for greater improvement and better living conditions in the states and the country in general. Majekodunmi (2013) and Onimisi, Samsu, Ismail, Nor, (2017) posits that the notion of federal character recognizes the plurality of Nigeria in employment processes, distribution of political and administrative positions as well as in the sharing of the country's resources across the board. The policy is strived at fostering equality in the composition and the conduct of the government's institutional practices which reflect the diversity of the country and recognizes the pluralist nature of Nigeria during employment exercises. The Federal Character Policy can reawaken a sense of belonging among the citizenry (Majekodunmi, 2013). Furthermore, Ojo (1999) supported the integrative perspective of Majekodunmi (2013) in his study of the policy and practice of federal character. He sees the federal character as an integrative mechanism that ensures fair and effective representation of all Nigerians (including those from minority ethnic groups) in all institutions of government.

Akinwale (2014), in his study of employment in the Nigerian civil service, focused attention on the representative aspect of the Federal Character Policy. He sees the Federal Character Policy as a significant facet of employment policy in the civil service of Nigeria designed to ensure and champion state representation in all national employments across the federation. In a similar way, Wahab (2009) points out that Federal Character Policy is a valuable aspect of the Nigerian employment process as it does not only ensure equality in employment distribution it guarantees representation across the board. Wahab (2009) emphasized that the introduction of the Federal Character Policy is a meaningful measure to strike a political balance through representation in employment in the Nigerian civil service. The objective of the Federal Character Policy is to strengthen and ensure adequate representation among the different sections of the country (Asaju, 2015; Onimisi, Samsu, Ismail, Nor, 2018). Their definition is limited to just representation with little or no emphasis on equitable representation of all facets of the country cutting across the states and geopolitical zones.

Oyedeji (2016) worked on the dynamics of the Federal Character Policy in Nigeria with a focus on the background of the policy through the Federal Character Commission of Nigeria (FCCN). Oyedeji sees it as a response mechanism of the federal government to the numerous, divisive and complex employment issues which abound in the states of the federation. In the same way, Asaju and Egberi (2015), in a comprehensive review of the Federal Character Policy see the policy as a deliberate attempt to construct a meaningful and proper distribution of government's amenities including employment. It has been used by successive governments in Nigeria to confront and mitigate the numerous challenges of diversity in order to guarantee and ensure a stable, peaceful and united country. Oyedeji (2016) and Asaju and Egberi's (2015) definitions highlight some important aspects of the policy but they fall short of the real essence of the agenda of the Federal Character Policy, which is to implement equitable representation of the various states, sections and geo-political zones in the country in the employment process of the federal government.

\section{B. The Act Establishing the Federal Character Policy}

The Federal Character Policy of Nigeria was formally established by Section 153 (1) of the 1999 constitution, whose foundation was laid by Decree No. 34 of 1996 under the military regime of General Sanni Abacha based on the recommendations of the 1994/1995 constitutional conference of Nigeria to implement and enforce the policy of federal character of equality in the distribution into the Nigerian civil service and the public service in general (Akinwale, 2014). The policy was placed under the Federal Character Commission which was enacted to give effect to Section of 14 the constitution of the Federal Republic of Nigeria which states. The principle and formulae for distribution of position in Federal Character Policy are further empowered by Section 4 (1) of the Act Establishing the Federal Character Commission Cap F7 Laws of the Federal Republic of Nigeria state.

The ACT establishing the Federal Character Commission with particular reference to Part 3 of Federal Character Policy and procedure for employment into the Federal Civil Service of Nigeria as stated in the Handbooks of the Federal Character Commission (2013) is as follows:

1. Each Ministry, Department, and Agency (MDA) shall ensure comprehensive manpower planning, procedure, and guidelines in accordance with its employment (manning/staffing level);

2. During the process of employment of staffs; available vacancies shall be identified and harvested using cadre by cadre;

3. Federal Character Policy shall be applied in the vacancies to be filled as pre-determined in relation to representation at the current level, by state or geopolitical zones;

4. The Ministries, Departments, and Agencies (MDA) shall provide and ensure comprehensive and proper job description (cognate experience/academic qualifications) needed for each position that is vacant;

5. Each and every vacancy shall be advertised in two or more newspapers with a national spread, and a minimum of six weeks given to prospective candidates to apply;

6. The allotted vacancies shall be filled with sufficient consideration given to the physically challenged and gender representation;

7. Where candidates are mandated to apply using the online platform, hard copies of the same applications shall equally be accepted; 
8. Where candidates are required to purchase Scratch Cards, One Thousand Naira shall be the maximum cost of the card

\section{Theoretical Framework}

The paper explores the group and game theories as a theoretical framework. Bentley (1949), Dahl (1956), Slaughter (1978), Takamichi (1985) and Truman (1951) who are leading advocates of the group theory of politics argue that public policy is majorly the product of struggle among the groups that make up a country. Groups struggle constantly to sway the government's policy outcome in their favor and the interaction and struggle of these groups is a core aspect of political life. Undoubtedly, this is the true representation of the Nigerian situation where there exists a continuous struggle among the groups to influence employment distribution in the Nigerian civil service. While the game theory scholars such as Neumann, Morgenstern, Kaplan, Riker, Schelling, and O'Toole posit that the major hindrance to policy implementation comes from lack of collaboration among the actors, the difference in priorities and targeted outcome among the key players are also other factors (Hermans, et al 2014). The game theory helps to provide some clarification on the social dilemmas that policy implementers face in the course of implementation; it equally assists in answering the 'why' question in policy implementation studies as well as clarifying the basic mechanism which helps to explain the policy outcome.

The framework shows that group and game theories aptly capture the issues surrounding the implementation of Federal Character Policy. Group theory illustrates how the Federal Character Policy itself emerged to ensure equal employment distribution in the Nigerian civil service. However, the persistent cases of disparity and failure in the implementation of the policy became issues of concern. Thus, to resolve these concerns and better appraisal the issue of implementation of the policy. The Game theory provided the needed avenue for understanding the Federal Character Policy. Although, the critics of the group theory have questioned some of its assumptions such as the importance it places on groups, the failure to represent all interests and its relegation of the role that government officials play in policymaking. Notwithstanding group theory does focus attention on the vital role played by groups like states and geopolitical zones in the policy process of the government (Bentley, 1949; Dahl, 1956). Game theory helps in explaining the outcome of interaction or public policy implementation which is based on rational choices of policy actors. Public policy in the group theory context is derived from group interests that are in constant interaction with the policymakers in order to influence their policy decisions. Group theory fits into this research because of the theory's usefulness in the description of public policy analysis studies of implementation of the Federal Character Policy in the Nigerian civil service and it shows a shared belief, interest or attitude transformed into ethnic groups and states struggling collectively to influence policymaking in their favor. Judging from the fact that the Federal Character Policy came about as a result of struggle among various groups in Nigeria for equal employment representation in the Nigerian civil service, Hermans, et al (2014) through game theory provided a better understanding of how policy implementation failures is ensured by critically assessing the role of various policy implementation actors such as staffs of the agency responsible for carrying out policy decision.

The theories are suitable for this paper because of their basic assumption that policy formulation is a reaction to the competition among the groups in a country, which adequately captures the Nigerian situation. The Nigeria situation is such that over 400 ethnic groups which make up the six (6) geopolitical zones of the country recurrently struggle to accrue more employment into the Nigerian civil service for their kinsmen. While the assumptions of game theory allows for an understanding of policy outcomes by assessing and critically evaluating all actors involved in the overall policy process, they subsequently bring forward the rationale behind every decision in the entire policy implementation process as well as the failure in the implementation the policy. The theories appropriately help in explaining the reasons for the failure in the implementation of the Federal Character Policy in the Nigerian civil service especially as they hold that external factors can influence the implementation of a policy agenda of the government.

\section{Methodology}

The paper adopted the qualitative design because it allows for pragmatic quest into the phenomenon under investigation and interpretation of the life experiences of the key stakeholders and importantly implementers of this policy and people of concern (Curry, et al 2009; Rubin and Luck 2009). Furthermore, a phenomenological approach was used because it allowed for pragmatic emphasis on the life experiences of the study key informants (Creswell, 2003). This approached involved the selected key informants to describe their life experiences as it relates to the phenomenon under investigation with the aim of exploring, identifying, comprehending and drawing the fundamental substance from them (Brent, 2017; Leedy \& Ormrod, 2001). The study location is Federal Capital Territory Abuja, Nigeria which is the administrative headquarter of Federal Character Commission and Nigerian Civil Service Commission the study under investigation rest there.

Data were collected through an interview of key informants and relevant documents were equally used to support the interviewed conducted. With the use of purposive sampling ten (10) key informants were selected from both Federal Civil Service of Nigeria and the Federal Character Commission based on their first-hand knowledge of the subject of the research and ability to the community this knowledge and experiences (Creswell \& Plano, 2011; Patton, 2002). Subsequently, a semi-structured interview was conducted was it allowed the informants to answer prepared open-ended questions and its flexibility made it most suitable for the research (Merriam, 2009). The paper also analyzed relevant documents such as the annual reports of the agencies of government concern, while manuals, scholarly journal articles, books, and brochures were equally subjected to analysis. It was subsequently followed with Interpretative Phenomenological Analysis (IPA), which began with transcription of data, categorization, emergence and elaboration of 
the themes and sub-themes interpreting and description of finding (Creswell 2003; Smith \& Osborn, 2003).

\section{ENSURING THE IMPLEMENTATION OF THE FEDERAL Character Policy in Nigerian Civil Service}

Three board themes emerged from the analyses which are an inclusion of all stakeholders in the implementation; application of sanctions and monitoring; and communication and training. The interview questions was aimed at how to ensure the implementation of Federal Character Policy in the Nigerian civil service employment distribution. It is imperative to note that prior studies have noted the need for implementation of the Federal Character Policy in Nigerian civil service (Mustapha, 2007; Ibor, et al, 2015; Oyedeji, 2016; Okorie and Onwe 2015). However, the biggest challenge confronting this policy today is how to ensure and improve the implementation of Federal Character Policy in the Nigerian civil service.

This paper found that in order to ensure the implementation of the Federal Character Policy in the Nigerian civil service there is the need to have an inclusive strategy, which is to ensure that major stakeholders like the civil society organization in the country, experienced policy implementers are identified and carried along, while the aspect of sanctions must be strengthened, it equally found that there is the need to carry out continuous evaluation and training in order to ensure the implementation of the Federal Character Policy in the Nigerian civil service.

\section{A. Role of Policy Implementers}

The policy implementers have a role to play the data analysis shows. The full inclusion of the policy implementers in the Federal Character Commission and those of the Federal Civil Service Commission an Informant stressed can ensure the implementation of the policy. The policy implementers in the Federal Character Commission whose responsibility is to ensure the implementation of the policy need to be awakened to sit-up if the objectives of the policy are to be implemented in the Nigerian civil service employment distribution. Thus, from the data gathered the awakening of the policy implementers would ensure and guarantee the implementation of the Federal Character Policy in the Nigerian civil service.

The findings show that for Federal Character Policy to be implemented in the Nigerian civil service an all-inclusive implementation measure is needed to ensure the achievement of policy objectives. Popoola \& Alao (2017) in their study of civil society organization and its influence in public policy in Nigeria Fourth Republic, found that the active involvement or inclusion of civil society is promptly required to galvanize public policy process especially the implementers of such policy, and by providing a synergy between public policy formulation and effective implementation of policy in Nigeria. These findings also agree with the discoveries of other studies which stressed the imperative of involving experienced policy implementers in order to ensure the implementation of Federal Character Policy in the Nigerian civil service. For instance, Nnajiofor, Ifeakor, \& Mgbemena (2013) in their study of the enigma of policy implementation in Nigeria opined that policy implementers have a role to play for the government and its agencies to realize their policy objective and for effective public policy implementation there is the need to engage qualified and experienced policy implementers. Thus, judging from the findings awakens policy implementers to their responsibility in the commission to ensure the implementation of the Federal Character Policy in the Nigerian civil service.

\section{B. Committed Leadership Involvement}

The implementation of the Federal Character Policy in the Nigerian civil service can be ensured where their committed leadership involvement in the implementation process. The data gathered from the informants basically shows that the Federal Character Policy implementation can be ensured in the Nigerian civil service once the leadership of the Federal Character Commission whose responsibility is to ensure the implementation of the policy in Nigeria wake up to their responsibility and present some level of commitment to the policy and their job, only then can the policy be best implemented. Informant emphatically stressed that if the implementation of the policy must take place the leadership has to be committed to it. While collaborating the role of committed leadership in to the implementation of the Federal Character Policy was another informant who expressed concern that if the leadership in the Federal Character Commission raise their level of commitment to the achieving the objective of the Federal Character Policy, implementing the policy in the Nigerian civil service will not be an issue.

The current research found that committed leadership involvement both from government and bodies responsible for the implementation of the Federal Character Policy in Nigerian civil service would guarantee the implementation of the policy in the country's civil service. This finding further supports the idea of Fadel (2014), who opined that effective and committed leadership, would yield the intended results and objectives, which will invariably lead to the convincing implementation of policy. Policy implementation requires implementation competencies and leadership commitment that will champion and ensure the effective implementation of public policy (Fadel, 2014). These findings are in agreement with Hartley and Allison (2000) which opined that in order to ensure the implementation of the policy of this nature, especially when it has to do with employment distribution, leadership responsibility and commitment must be assumed by policy implementers in their various and respective units.

This research produced findings which corroborate the result of a great deal of previous work carried out by Van Wyk \& Pelser (2014) who opined that leadership involvement in the policy process remains the key factor that can ensure the effective implementation of policies, especially when such leadership role is assumed by the policy implementers. Similarly, Abdulsalam (2006) believes that the effective implementation of public policy in Nigeria highly depends on the role of government leadership players through its policy implementers. In accordance with the present findings, Ugwuanyi \& Chukwuemeka (2013) equally opined that purposeful leadership at various 
government units and commitment and dedication can ensure the effective implementation of Nigerian public policies, this case the Federal Character Policy implementation in the Nigerian civil service. This study confirms the work of Azhar, Ikram, Rashid, \& Saqib (2013) in their study of the role of leadership in policy formulation and implementation where they opined that implementation of the governmental policy rest of the vital role and drive of the leadership of such policy body. In accordance with the current findings, committed leadership from the policy implementers in the body, when raised can ensure the implementation of the Federal Character Policy in the Nigerian civil service.

\section{Adequate Budgetary Provision}

The place for effective monitoring and evaluation in the implementation of the Federal Character Policy in the Nigerian civil service was stressed by some informants who see it as a guarantee for policy implementation. In this case, the informant opined that the implementation of the Federal Character Policy in the Nigerian civil service would be better ensured when there is adequate budgetary provision to ensure effective monitoring which will invariably help the commission in ensuring the policy is implemented in the country's civil service. The importance of adequate provision as a tool to ensuring the implementation of the Federal Character Policy in the Nigerian civil service was equally stressed by another Informant, who believed that no meaningful implementation of the policy can take place without effective budgetary provision. The funding through the adequate provision for budgeting, the informant believes is the basic tool needed for the implementation of the Federal Character Policy in the Nigerian civil service, as implementation is ensured when this provision is taken care of.

This research finding shows that adequate budgetary provision would ensure the implementation of the Federal Character Policy in the Nigerian civil service employment distribution. In accordance with the present finding, previous research by Ahmed \& Dantata (2016) has demonstrated the importance of implementation in public policy and stressed closer/constant improvement in the budgeting of the process of implementation to ensure effective implementation of public policy. This research finding further support the idea of Briggs (2007) who opined that improved funding helps to ensure the implementation of the Federal Character Policy objectively in the Nigerian civil service. The finding further supports the ideals of Kusek \& Rist (2004) who opined that planning and budgeting effectively provide information on how to ensure the implementation of program and policies of the government at given time (and over a period of time) as it relates to the respective policy targets and outcomes.

In accordance with the present finding the implementation of the Federal Character Policy in the Nigerian civil service can be best achieved and ensured where there is continuous improvement in the budgetary provision this research observed and this would go a long way in ensuring the policy implementation. These findings seem to be consistent with other research carried out by Sapru (2011) in his studies of the art and craft of public policy analysis, where he demonstrated that the implementation of public goal can be best achieved when there is an existence of effective and improve budgetary provision. Sapru (2011) further opined that adequate provision in the budgeting system remains the heart of policy implementation because it helps the implementers of policy to get the greatest result of the said policy. Furthermore, this research produced findings which corroborate the work of Eghe \& Paul (2015) to a great deal in their study of budget and policy implementation in Nigeria, where they opined that adequate budgetary brings breath to policy process and makes implementation of the policy a reality.

\section{FUNDING FOR ADEQUATE MONITORING}

It was also suggested from the data analysis that adequate funding provision for monitoring, when put in place, can ensure the implementation of Federal Character Policy in the Nigerian civil service. The informant stresses the pivotal role funding of the commission would play to ensure it meets the policy's core mandate. The informant emphatically opined that absence of funding remains the biggest constraints of the policy, thus if and when funding is provided the implementation of the Federal Character Policy in the Nigerian civil service will be done to the fullest. Informant stressed that funding provision for the monitoring of the policy was clearly needed to ensure implementation. The issue of funding for effective monitoring, the informants believes to be hindering the implementation of the Federal Character Policy in the Nigerian civil service. The Informant opined that monitoring remains one of the cardinal issues rounding the implementation of policy, thus the adequate provision of funds for effective monitoring would go a long way in ensuring the implementation of the Federal Character Policy in the Nigerian civil service.

This finding is consistent with that of Chandler (2016) who opined that to guarantee the implementation of public policy, authorities concerned must ensure and demand perfect monitoring of compliance within a time frame provided for by such policy. Agbodike \& Igbokwe-Ibeto (2005) further supported the idea of the application of enforcement/monitoring to determine and ensure the implementation of the Federal Character Policy in the Nigerian civil service. Similarly, Ugoh \& Ukpere (2012) opined that since monitoring of compliance forms part of the Federal Character Policy mandate, which can be pursued through the courts of the land, thus the sufficient enforcement of the constitutional provision of the policy by the implementing bodies can ensure the implementation of the policy in the Nigerian civil service employment distribution.

It is encouraging to compare this finding with that found by Crosby (1996) who opined that analytical potential for implementation rests on monitoring, thus this current research found that for the implementation of the Federal Character Policy to be possible in the Nigerian civil service there is the need to take monitoring seriously, and when monitoring is adequately funded the implementation of such policy is ensured. This finding corroborates the ideas of Kresnaliyska (2015), who suggested that monitoring is a dynamic and intense process which is systematically supported by the flow of public policy, and importantly

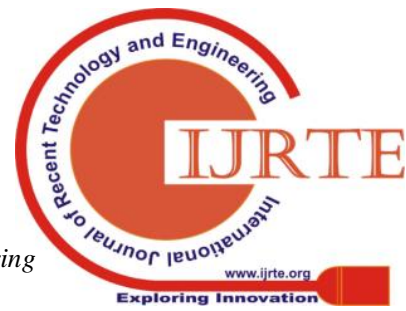


request funding to position it efficiently in the overall good of policy implementation.

\section{E. Establishing Communication Link}

The establishment of a concrete communication link between the bodies would ensure the implementation of the Federal Character Policy in the Nigerian civil service this paper found. An important sub-theme that emerged at this stage of data analysis is communication synergy; the informants believe that establishing a communication link is a core issue to consider if the policy is to be implemented. An Informant expresses the desire that if the implementation is to be ensured and the Federal Character Policy in the Nigerian civil service is to be guaranteed the communication link must be strengthened. The informant explicitly stresses the need for continuous back and forth communication between the Federal Character Commission whose responsibility is to ensure the implementation of the policy and the Civil Service Commission who provides employment into the Nigerian civil service.

Similarly, Another Informant explicitly stated the implementation of the Federal Character Policy in the Nigerian civil service strongly rests on communication. The informant's position corroborates the view of the other informants about strengthening the communication link between the two bodies. This important finding shows that effective communication link amongst the key shareholders involved in carrying out employment into the civil service and those involved in the monitoring policy can ensure the successful implementation of the Federal Character Policy in the Nigerian civil service employment distribution. This finding is consistent with that of Panos (2007) which stressed that communication link which involves an exchange of valuable information, negotiation and understanding among key policy actors would ensure implementation of any planned program of the government. Furthermore, effective and established communication link according to Kakonge (2012) in a public policy can ensure the improvement and success of such policy especially at the implementation stage, this position collaborates the finding of the current study.

This finding which shows that effective communication link between the officers of the Federal Character Policy and the Nigerian civil service can guarantee the implementation of the policy of equal employment distribution in the country's civil service. This broadly supports and aligns with the work of Sondej (2015) in his studies of operational policy making, where he opined that effective and well-established communication link helps to facilitate and ensure the improvement of policy implementation which is necessary for change to occur in any given country.

\section{F. Orientation}

Another important finding from the data analysis shows the role of orientation in the implementation of the Federal Character Policy in the Nigerian civil service. The orientation of the personnel in the Commission whose responsibility is focused on ensuring the implementation of the Federal Character Policy in the Nigerian civil service the informants believe would assist in ensuring the implementation of the policy. The Informant was emphatic that this can ensure the implementation of the Federal
Character Policy in the Nigerian civil service. The informant's position is centered on the view that when the policy implementers, as well as the general public, are aware of the imperative of the policy, its implementation can be ensured. Explicitly expressing this position was another informant who believes the all-around education of the citizenry through orientation remains the core tool for ensuring the implementation of the Federal Character Policy in the Nigerian civil service employment distribution. The informant further shows that orientation would bring about the general public in the implementation process of the Federal Character Policy thus promptly ensuring it objectives are carried out in the Nigerian civil service.

The findings suggest that to ensure the implementation of the Federal Character Policy in the Nigerian civil service the person whose responsibility is to ensure the implementation of policy and the general public need to be given orientation on the major tenets of the federal character and the need to promptly take the implementation seriously. In accordance with the current findings, Okotoni \& Erero (2005) have demonstrated early that rapid change in policy implementation cycle necessitates the continuous need for personnel sanitization and training in order to acquire the skills and knowledge required for implementation of policy.

\section{G. Training}

The sub-theme emanating from the data analysis shows that those responsible for implementation of Federal Character Policy needs constant training on the new and innovative ways of carrying policy implementation. The Informant emphasizes the need for training and retraining of the staff since policy implementation can be dynamic, thus the training of those responsible for the implementation of the Federal Character Policy in the Nigerian civil service needs to catch up with current trends of policy implementation, which invariably would be of great significance in ensuring the implementation of the said policy. Similarly, an informant corroborates this position on the imperative of staff training aimed at ensuring the implementation of the Federal Character Policy in the Nigerian civil service. Talking about this issue of training, the Informant identified the importance of this Federal Character Policy and the need for it to be implemented to the latter since it is to ensure job spread across the states in Nigerian civil service, thus training of those saddled with such responsibilities needs to be taken seriously in order to achieve the required objective. It is worthy of note that the implementation of the Federal Character Policy in the Nigerian civil service can be ensured through renewed training of personnel on the tenets of the policy implementation and the needed impetus to achieving this all-important task of implementation. Equally important to note is that the current research produced findings which corroborates the results to a great deal of previous work which shows that orientation and training can facilitate and ensure the improvement in the implementation of public policy (Wallace, 2009).

Furthermore, Wallace (2009) believes that orientation and training help to clarify expectations provides reliable information and contribute to a more positive and good communication between the public policy implementers 
which will in a long run ensure the implementation of policy task before them. In accordance with the present findings which shows that the implementation of the Federal Character Policy in the Nigerian civil service employment distribution can be achieved through orientations and training of the concerned staffs of both agencies of the government. This has equally been demonstrated by Ayeni (2002) in his work on public sector reform where he stressed that training and re-orientation of the civil servant, political office holders as well as policy implementers can ensure the effective and improved public policy implementation.

\section{CONCLUSION}

The paper established that the implementation of Federal Character Policy which was enacted to ensure equal employment distribution in Nigerian civil service can be best ensured through when their an all-inclusive implementation mechanism. The paper stresses the need for inclusion of civil society organization to checkmate and serve as a watchdog to those actions and inaction of policy implementers in both the Federal Character Commission and the Federal Civil Service Commission who are not carrying to objectives to the policy. The paper further demonstrated that the implementation of the Federal Character Policy in Nigeria guaranteed the establishment of robust communication between the agencies concern with the implementation. It is important to note that finding the shows that adequate funding and training of personnel responsible for the implementation of policies would equally help in ensuring that the policy is implemented. Finally, the paper demonstrated that application of necessary sanction to defaulted of the policy can ensure its implementation and the establishment of Federal Character Tribunal would provide a golden opportunity that ensures that policy is implemented in Nigeria.

\section{REFERENCES}

1. I. Abdulsalam. The Role of Public Administration in National Development Strategy: Challenges and Prospects. Management in Nigeria 2006 43(1) pp. 28-34

2. K. I. Ahmad \& S. B. Dantata, Problems and Challenges of Policy Implementation for National Development Research on Humanities and Social Sciences 2016 Vol.6, No.15 pp. 60-65

3. F. Agbodike. \& C.J. Igbokwe-Ibeto. Recruitment Policies in the Nigerian Federal Civil Service and Their Implications on Employees Performance Kuwait Chapter of Arabian Journal of Business and Management Review, 2015 5(3) pp. 34-48.

4. E.J.A. Akinyemi. (2014) Civil Service Recruitment: Problems Connected with Federal Character Policy in Nigeria Journal of Public Administration and Governance 2014. 4 No. 2

5. K. Asaju. Democratic Governance, Federal Character Principles and National Development In Nigeria Review of Public Administration and Management. 2015. Vol. 4, No. 8 pp 172-187

6. K. Asaju. \& T. Egberi. Federal Character and National Integration in Nigeria: The Need for Discretion and Interface Review of History and Political Science. 2015 Vol. 3, No. 1, pp. 126-134

7. V. Ayeni. Public sector reform in developing countries: a handbook of Commonwealth experiences (No. 14). Commonwealth Secretariat 2002)

8. A. Azhar, S. Ikram, S. Rashid \& S. Saqib. The role of leadership in strategy formulation and implementation. Studies. 2013 1(2)

9. A.F. Bentley. (1949) The Process Of Government: A Study Of Social Pressure Evanston III: Principia Press 1949

10. M. Brent. The Five Approaches to Qualitative Research Retrieved from (10/05/2017) qualitative-research-4427.html

11. B. R. Briggs. Problems of recruitment in civil service: case of the Nigerian civil service. African journal of business management. 2007 1(6).
12. J. A. Chandler. Public Policy and Private Interest: Ideas, Self-interest and Ethics in Public Policy. Taylor \& Francis 2016.

13. O. O. Cornelius, O. O., \& E. Greg. Federal Character Principles, Nation Building and National Integration in Nigeria: Issues and Options. Mediterranean Journal of Social Sciences. 20134(16), 33

14. J. Creswell. Research design: Qualitative, quantitative and mixed methods approach (2nd ed.) (2003). Thousand Oaks, CA: SAGE Publications

15. J. W. Creswell. \& V. L. Plano Clark. (2011) Designing and Conducting Mixed Methods Research (2nd ed.). 2011 London: Sage Publications Ltd

16. B. L. Crosby. Policy implementation: The organizational challenge. World Development 1996 24(9), 1403-1415.

17. L. A. Curry. I. M. Nembhard \& E. H. Bradley. (2009) Qualitative and mixed methods provide unique contributions to outcomes research. Circulation, 2009 119(10), 1442-1452.

18. R. Dahl. A Preface To Democratic Theory. Chicago: University of Chicago Press. 1956

19. M. Fadel. Leadership, Governance and Public Policy Implementation Competencies in the Broader Public Sector European Journal of Business and Management 2014 Vol.6, No.36

20. Federal Character Commission Handbook (2013) Abuja Presidency

21. J. Hartley \& M. Allison. The modernization and improvement of government and public services: The role of leadership in the modernization and improvement of public services. Public money and management, 2000 20(2), 35-40.

22. L. Hermans, S. Cunningham, \& J. Slinger. The usefulness of game theory as a method for policy evaluation Evaluation (2014) 20(1) $10-25$.

23. W. U. Ibor, F. Egolikuma, \& D. Isa. (2015) Spatial Analysis of Employment Distribution in The Federal Civil Service, Nigeria Mediterranean Journal of Social Sciences 201551 265-276

24. O. J. Kakonge. Improving Development Project Implementation through Effective Communications 2012 Retrieved20/02/2018 from http://www.globalpolicyjournal.com/blog/25/10/2012/improvingdevelopment-project- implementation-through-effectivecommunications 2

25. G. Kresnaliyska. Monitoring of Public Policies - A Modern Tool of Good Governance American International Journal of Contemporary Research 2015Vol. 5, No. 5

26. J. Z. Kusek \& R. C. Rist. Ten steps to a results-based monitoring and evaluation system: a handbook for development practitioners. World Bank Publications. 2004

27. P. Leedy \& J. Ormrod. Practical research: Planning and design (7th ed.). 2001 Upper Saddle River, NJ: Merrill Prentice Hall. Thousand Oaks: SAGE Publications

28. A. Majekodunmi, A. (2013) Federal Character Principle As A Recipe For National Integration In Nigeria: An Overview, International Journal of Advanced Research in Management and Social Sciences 201326

29. B. S. Merriam. Qualitative Research: A guide to design and Implementation 2009San Francisco: Jossey-Bass

30. A. R. Mustapha, A. R. (2007). Institutionalizing ethnic representation: How effective is the Federal Character Commission in Nigeria? CRISE Working Paper No. 43, Centre for Research on Inequality, Human Security and Ethnicity (CRISE), (2007 University of Oxford, U.K.

31. A. R. Mustapha. Institutionalising ethnic representation: How effective is affirmative action in Nigeria? Journal of International Development 2009 21(4), 561-576.

32. O. G. Nnajiofor, C. S. Ifeakor \& S. Mgbemena. (2013). Nigeria and the enigma of policy implementation Creative Artist: A Journal of Theatre and Media Studies, 2013 7(2), 224-241.

33. E. Ojo. Mechanisms of National integration in a Multi-Ethnic Federation State: The Nigerian Experience. 2009 Ibadan: John Archers Publishers, Ltd.

34. O.C. Okorie \& O. S. Onwe. Implications of Separation of Powers and Federal Character Principle on Public Sector in Nigeria International Journal of Humanities Social Sciences and Education 2015)Vol. $2,(6) 35-41$

35. O. Okotoni \& J. Erero, (2005) Manpower training and development in the Nigerian public service African journal of public administration and management. 2005 16(1), 1-13 
36. T. Onimisi, K. H. K. Samsu, M. M. Ismail, M. W. M. Nor. Federal Character Principles: A Conceptual Analysis International Journal of Social Science and Humanities Research 2018. Vol. 6, Issue 2, pp: 172-177

37. T. Onimisi, K. H. K. Samsu, M. M. Ismail, M. W. M. Nor. The Nexus between Federal Character Policy and the Nigeria Civil Service International Journal of Social Science and Humanities Research 2017 Vol. 5, Issue 3, pp 346-349

38. B. Oyedeji. Background Issues to Federal Character Dynamics in Nigeria. International Journal of Innovative Development \& Policy Studies 20164 (1): 1, 12.

39. Panos. At the heart of Change: the role of communication in sustainable development 2007Panos, London, UK

40. M. Q. Patton. Qualitative research and evaluation methods 3rd Sage Publications; 2002 Thousand Oaks, CA

41. M. A. Popoola \& D. O. Alao. Civil Society Organisations and Public Policy Influence: The Nigerian Experience in the Fourth Republic. KIU Journal of Social Sciences, 2017 3(2), 15-24.

42. R. S. Rubin \& D. J. Luck Marketing Research 2009 Prentice hall of India: New Delhi

43. R. K. Sapru. Public policy: Art and craft of policy analysis. $2011 \mathrm{PHI}$ Learning Pvt. Ltd

44. J. A. Smith \& M. Osborn. Interpretative phenomenological analysis In J. A. Smith (Ed.), Qualitative psychology: A practical guide to methods London, UK: Sage. 2003 pp. 53-80.

45. A. Sondej. Operational Policy Making for Professional Security Practical Policy Skills for the Public and Private Sector. 2015 Butterworth-Heinemann

46. M. Takamichi. State Power, State Autonomy, and the Study of Transnational Relations Journal of International Studies 1985 Vol.14 49-76

47. D. B. Truman. The Governmental Process: Political Interests and Public Opinion New York: Alfred A. Knopf 1951

48. S. C. Ugoh \& W. I. Ukpere. Policy of the federal character principle and conflict management in Nigerian federalism. African Journal of Business Management, 2012 6(23), 6771-6780.

49. B. I. Ugwuanyi \& E. Chukwuemeka. The obstacles to effective policy implementation by the public bureaucracy in developing nations: the case of Nigeria. Singaporean Journal of Business, Economics and Management Studies, 2013 1(8), 34-43.

50. C. Van Wyk \& A. M. Pelser Leadership's role in effective implementation of school discipline policies. The International Business \& Economics Research Journal (Online), 2014 13(4), 833

51. M. A. Wahab, M.A. (2009). Civil Service Recruitment Policy in Bangladesh: A Critical Analysis. Paper Submitted for NAPSIMAG International Conference Malaysia Executive Development Centre Development Centre, University Utara, Malaysia, Kedah, 11 - 13 2009

52. K. L. Wallace, K. L. (2009) Creating an effective new employee orientation program 2009 (23/02/2018) Retrieved from https://journals.tdl.org/llm/index.php/llm/article/viewFile/1802/1077

\section{AUTHORS PROFILE}

Timothy Onimisi, currently lectures in the Department of Political Science, Federal University Lokoja, Kogi State, Nigeria. He has published a number of article on public policy and policy implementation in Nigeria in both local and international journals.

Associate Professor Dr. Ku Hasnita Ku Samsu, currently lectures in Department of Government and Civilization Studies, Faculty of Human Ecology, University Putra Malaysia. She has published many articles on political sociology in both local and international journals. She tutored and graduated quite a number of postgraduate students.

Dr. Mohd Mahadee bin Ismail, is a senior lecturer in Department of Government and Civilization Studies, Faculty of Human Ecology, University Putra Malaysia. He has published a number of article on Politics and Government and Southeast Asian.

Dr. Murni binti Wan Mohd Nor is a senior lecturer in Department of Government and Civilization Studies, Faculty of Human Ecology, University Putra Malaysia. He has published a number of article on both local and international journals. She is an expert in law. 